\title{
Combined Impacts of Native Grass Competition and Introduced Weevil Herbivory on Canada Thistle (Cirsium arvense)
}

\author{
Ángel Ferrero-Serrano, ${ }^{1}$ Timothy R. Collier, ${ }^{2}$ Ann L. Hild, ${ }^{3}$ Brian A. Mealor, ${ }^{4}$ and Thomas Smith ${ }^{5}$
}

Authors are ${ }^{1}$ Doctoral candidate, University of Liverpool, Liverpool, UK; ${ }^{2}$ Assistant Professor and ${ }^{3}$ Associate Professor, Department of Renewable Resources, University of Wyoming, Laramie, WY 82071-3354, USA; ${ }^{4}$ Director of Stewardship, The Nature Conservancy, Lander, WY 82520, USA; and ${ }^{5}$ Biologist, US Army Corps of Engineers, Engineer Research and Development Center, Construction Engineering Research Laboratory, Champaign, IL 61826-9005, USA.

\begin{abstract}
Invading exotics typically face new competitors and an absence of specialized herbivores in their new ranges. Biological control attempts to reunite invasive weeds with coevolved herbivores and restoration can reduce the return of invaders by maximizing competition from native species. The integration of both approaches is seldom examined in detail, although the two should complement each other. We investigated the potential to suppress an important invasive plant, Canada thistle (Cirsium arvense [L.] Scop.), by integrating biological control and competition from two native grasses frequently used in rangeland restoration. We evaluated the impacts of Ceutorhynchus litura F. (Coleoptera: Curculionidae), a weevil used for Canada thistle biological control, alone and in combination with either needle and thread grass (Hesperostipa comata [Trin. \& Rupr.] Barkworth) or alkali sacaton (Sporobolus airoides [Torr.] Torr.) in greenhouse competitive plantings. Weevil herbivory reduced root, but not shoot, biomass of Canada thistle. Competition from H. comata did not reduce biomass of thistles, but combinations of the weevil and H. comata greatly reduced thistle root biomass. S. airoides suppressed Canada thistle root biomass independent of weevils. Weevils had a positive indirect effect on the cool-season grass $\mathrm{H}$. comata, presumably by reducing the competitive ability of thistles, but had no effect on biomass of the warm-season grass, S. airoides. Benefits of weevil presence as an augmentation of grass competition appear to depend on appropriate timing, and weevils provided the most benefit to the coolseason competitor. Our results suggest that restoration efforts can be complemented with insect biocontrol agents, although the timing of impact will depend on the particular weed species, grass competitors, and biocontrol insect agents involved.
\end{abstract}

\section{Resumen}

Las especies exóticas invasoras en general enfrentan nuevos competidores y una ausencia de herbívoros especializados en sus nuevos rangos. El control biológico intenta reunir las malas hierbas con herbívoros co-evolucionados y la restauración puede reducir el retorno de invasores por lograr maximizar la competencia de especies nativas. La integración de ambos métodos es rara vez examinado en detalle, aunque los dos se deberían complementar entre sí. Nosotros investigamos el potencial para suprimir una importante planta invasora, Cardo triguero de Canadá (Cirsium arvense [L.] Scop.) mediante la integración del control biológico y la competencia de dos gramas nativas utilizadas frecuentemente en la restauración de pastizales. Nosotros evaluamos los impactos del Ceutorhynchus litura F. (Coleoptera: Curculionidae), un gorgojo utilizado para el control biológico del cardo triguero de Canadá, solo y en combinación con cualquiera de la "needle and thread grass" (Hesperostipa comata [Trin. \& Rupr.] Barkworth) ó "alkali sacaton" (Sporobolus airoides [Torr.] Torr.) en plantaciones competitivas de invernadero. La herbivoría del gorgojo redujo la raíz pero no el crecimiento de biomasa del cardo triguero de Canadá. La competencia de $H$. comata no redujo la biomasa de los cardos, pero las combinaciones del gorgojo y $H$. comata redujeron grandemente la biomasa de los cardos. Probolus airoides reprimió la biomasa en la raíz del cardo de Canadá independiente de los gorgojos. Los gorgojos tuvieron un efecto positivo indirecto en la hierba de temporada fría H. comata, se supone que por la reducción de la habilidad competitiva de los cardos, pero no tuvo efecto sobre la hierba de temporada cálida, S. airoides. Los beneficios de la presencia del gorgojo como el aumento de la competencia de hierba parecen depender del tiempo apropiado y los gorgojos proveen muchos beneficios al competidor en la temporada fría. Nuestros resultados sugieren que los esfuerzos de restauración pueden ser complementados con agentes entomológicos de biocontrol, aunque el tiempo adecuado del impacto dependerá en las especies particulares de hierba mala, hierbas competidoras y los agentes entomológicos de biocontrol involucrados.

Key Words: biological control, Ceutorhynchus litura, Hesperostipa comata, integrated pest management (IPM), Sporobolus airoides, synergism, weevil

\section{INTRODUCTION}

Research was funded in part by the Strategic Environmental Research and Development Program (SERDP SI-1389) and the US Army Corps of Engineers (ERDC-CERL).

At the time of the research, Ferrero-Serrano was a research assistant, Dept of Renewable Resources, University of Wyoming, Laramie, WY, USA.

Correspondence: Ann L. Hild, Dept of Renewable Resources, Dept 3354, University of Wyoming, 1000 E University Avenue, Laramie, WY 82071, USA. Email: annhild@uwyo.edu

Manuscript received 5 December 2007; manuscript accepted 16 June 2008.
Invasive exotic plants face novel conditions in their new ranges with respect to herbivory and competition. Neighbors of invasive plants in the new range may be less competitive with the invader because they lack a shared evolutionary history (Callaway and Ridenour 2004). Specialized natural enemies (predators and competitors) of the invader are also likely to be absent, releasing it from the negative impacts of coevolved 
herbivores (Keane and Crawley 2002). In such cases, active manipulation of competition and herbivory should provide the potential to combat invasive plant species. Competition may be provided by restoring invaded sites with highly competitive native species. Native plant species vary intrinsically in their ability to compete with a given exotic species (Wilson and Kachman 1999), and extended association with an exotic may select for increased competitive ability in native populations (Mealor and Hild 2006; Strauss et al. 2006).

Introduced biological control agents can reduce invasive plant populations by killing individual plants and by reducing fecundity (Myers and Bazely 2003). Biological control agents may also reduce the competitive ability of the targeted invader and, thereby, tip the competitive hierarchy in favor of native neighbors (Sheppard 1996; Sheppard et al. 2001).

Given the seemingly complementary connection between competition and herbivory, combining biological control agents with native competitors should represent a useful, integrative strategy for managing invasions. Integration of revegetation with weed biological control might be used to 1) enhance the impact of biological control agents, and 2) benefit the establishment of restored plant communities. However, the few studies that have used integrated control methods provide mixed results (Callaway et al. 1999; Collier et al. 2007), suggesting that interactions of control methods require further study. Plant competition and biological control agents often have independent or additive effects on invasive plant species (Sheppard 1996). In some cases, however, the impacts of biological control agents and plant competition have been greater than additive or synergistic effects (Müller-Schärer 1991; Ang et al. 1994, 1995; Notzold et al. 1998). In other words, the combined impact of two synergistic factors is greater than would be expected from the sum of independent effects. Synergy might arise, for example, if plants damaged by herbivory are less competitive with their neighbors or if invasive plants subjected to competition are less able to compensate for damage from biological control agents. When the two factors have less impact than would be expected from the sum of the independent effects they are considered subadditive, the opposite of synergistic. Synergy is clearly the most desirable outcome in integrating management strategies for invasive plant species. Although additive impacts are also desirable, integration of subadditive strategies should be avoided.

The notion that biological control agents should benefit the plant neighbors associated with the invader seems intuitive but has rarely been addressed. Müller-Schärer and Schroeder (1993) considered the impacts of domestic herbivory as capable of tipping the balance of competitive interactions to favor nonpalatable invaders and also suggested that increased competitive status of neighboring plants should assist the impact of biological control agents against weeds. Harris (1991) describes a cumulative stressors approach to control and suggests that introduction of multiple insects and competitive neighbors may conceivably be more effective in limiting invaders. The one study that investigated the indirect effect of a biological control agent on competitive neighbors (Callaway et al. 1999) found that a root-feeding moth (Agapeta zoegana) had little effect on the invasive spotted knapweed (Centaurea stoebe $\mathrm{L} .=$ maculosa), and actually harmed neighboring native grass indirectly by making the knapweed more aggressive following herbivory by eliciting a compensatory growth response from the knapweed. Clearly, biological control agents that harm native plants species should be avoided if subadditive interactions can be anticipated.

In attempting to integrate restoration of native communities with weed biological control, the combined impacts of competition and herbivory are likely to vary considerably depending on the phenology of the species involved. Synchronization of agent activity with the timing of growth of the invasive plant species is an important consideration in weed biological control (Harris 1973). Likewise, the effectiveness of competitive grasses for restoring invaded sites may be enhanced by matching the phenology of the grass to that of the invasive species. For example, cool-season grasses (C3 competitor) may be more competitive with a C3 invasive plant species than warm-season grasses ( $\mathrm{C} 4$ competitor) because of the greater overlap in the timing of nutrient acquisition. Synchronization of competition and herbivory might also achieve greater impact from combinations of competition and biological control. Although these are important considerations in integrating biological control and ecological restoration, studies that vary the phenology of competitors do not exist.

We examined the potential for integrating biological control (the stem-mining weevil Ceutorhynchus litura F. (Coleoptera: Curculionidae) and grass competition on an important invasive plant species, Canada thistle (Cirsium arvense [L.] Scop.). Canada thistle is a deep-rooted, colony-forming perennial that is present in 41, and considered noxious in 33, US states and six Canadian provinces (US Department of Agriculture-Natural Resources Conservation Service [USDA-NRCS] 2007). C. arvense is highly invasive in upland pastures, grasslands, and riparian ecosystems, where it can dominate communities and reduce production for livestock grazing and agricultural crops. Vegetative growth from a deep, creeping root system (Nadeau and Vandenborn 1989) makes C. arvense difficult to manage with herbicides or mechanical controls. Consequently, C. arvense was targeted for biological control using introduced insects, starting in the 1950s (Piper and Andres 1995).

Ceutorhynchus litura, a stem-mining weevil from Europe, is considered to be the most effective agent available for $C$. arvense (Coombs et al. 2004). Studies on the impact of the weevil provide mixed results; some studies document declines in thistle density following release (Rees 1990), whereas others reveal no impact (Peschken and Derby 1992; Reed et al. 2006). Herbivory by C. litura reduces levels of sugars (Peschken and Derby 1992) and starches (Hein and Robert 2004) in C. arvense roots, but plants compensate or overcompensate for these reductions by the end of the growing season. Female weevils feed and oviposit on thistles in the late spring. Larvae feed on parenchyma tissue inside stems and leaf veins (Peschken and Wilkinson 1981) and then exit the plant in midsummer to pupate in the soil. Adults emerge in late summer and overwinter in the leaf litter.

We used needle and thread grass (Hesperostipa comata [Trin. \& Rupr.] Barkworth), a cool season, C3 grass, and alkali sacaton (Sporobolus airoides [Torr.] Torr.), a warm season, C4 grass, for our study to vary phenology of the competitors. The grasses can co-occur with C. arvense in upland, grassland sites and wetter, low-lying pastures and riparian areas (US 
Department of Agriculture-US Forest Service [USFS] 2007). Both grasses are useful for stabilizing soils on eroded sites and are commonly used in reclamation settings throughout the West (USDA-USFS 2007) and are, thus, potential competitors with the weed in restoration seedings. H. comata grows early in spring and becomes dormant during hot weather. S. airoides is commonly present in saline sites in the Great Plains and Great Basin (USDA-NRCS 2007a).

We hypothesized that grass competition and attack by the weevil would have synergistic impacts on the growth and biomass of Canada thistle. We also expected that the two grass species used in the experiments would differ in their impact on Canada thistle alone and in combination with the weevil because they differ in phenology and photosynthetic pathway. Specifically, we hypothesized that 1) combined treatments of grass competition and weevil herbivory would have synergistic impacts on C. arvense; 2) that the weevil would have indirect, beneficial effects on the performance of grasses growing in competition with C. arvense; and 3) that the grass species, because they differ in phenology, would also differ in their impact on C. arvense, alone and in combination with the weevil.

\section{MATERIALS AND METHODS}

\section{Collection and Handling of Plant Materials and Insects}

Accessions of both grasses ( $H$. comata and $S$. airoides) were collected from field settings for use in the study. S. airoides was collected near Greybull and Laramie, Wyoming, and Naturita, Colorado. H. comata was collected near Riverton and Laramie, Wyoming, and Mud Lake, Idaho. Large individuals (approximately $25-\mathrm{cm}$ diameter) of each native grass species were excavated and transported to the greenhouse facilities at the University of Wyoming, Laramie, Wyoming. Once the plants were in the greenhouse, each individual was divided into multiple clones and repotted to allow recovery following division.

C. arvense roots were collected near Cheyenne, Wyoming, in March 2005. On 1 April 2005, 10-cm-long root segments of similar diameter were placed into trays. On 24 and 25 April 2005, grasses and thistles were randomly assigned for planting into $15 \mathrm{~cm} \times 45 \mathrm{~cm}$ polyvinyl chloride (PVC) columns containing a medium of sand and peat soil (1:1 by volume). Experimental plants were grown in about $8000-\mathrm{cm}^{3}$ soil media in $15-\mathrm{cm}$ diameter $\times 45-\mathrm{cm}$ tall PVC columns in the greenhouse, which allowed us to manipulate the presence of the weevil and to harvest both aboveground and belowground biomass of the plants. We were especially interested in the impacts of herbivory and competition on root biomass of $C$. arvense because $C$. arvense reproduces so aggressively from adventitious root buds (Nadeau and Vandenborn 1989). The pot shape (column) was intended to allow for deep penetration of thistle and grass roots. Plants were grown under $30^{\circ} \mathrm{C}$ day and $20^{\circ} \mathrm{C}$ night temperatures. Plants were watered immediately after planting and once per week thereafter. Lighting was ambient, and day length varied from 15 hours in June to 10 hours in December. On 12 May 2005, five adult C. litura, purchased from a commercial source (Integrated Control of Weeds, Bozeman, MT), were placed onto each C. arvense in the herbivory treatments to allow oviposition and adult feeding. Gender of beetles was not noted because it was impractical; difficulty in determining sex requires excessive handling of each insect. With the addition of five weevils per thistle plant and a 50-50 sex ratio, $97 \%$ of plants would have received at least one female weevil and $62 \%$ would have received at least two female weevils. Given that each treatment was applied to 10 pots, the amount of oviposition should have been randomly dispersed among treatments. Plants in all treatments were covered with polyester-mesh sleeve cages. On 20 May 2005, the cages and adult weevils were removed. The five experimental blocks were harvested at 2-wk intervals from 15 October 2005 to 10 December 2005. As a consequence, blocks 1 and 5 differed in age at the time of harvest by $8 \mathrm{wk}$. At harvest, leaves of $C$. arvense plants were removed to measure leaf area using a leaf-area meter (LI-COR, Lincoln, NE). We also recorded the number of shoots on C. arvense plants. Roots were separated from the soil medium by washing in a sieve. The height of the pots (columns) allowed roots to extend without depth restrictions. Roots and shoots of C. arvense and grasses were oven-dried separately at $65^{\circ} \mathrm{C}$ for $36 \mathrm{~h}$ and weighed.

\section{Experimental Design and Analyses}

C. arvense was subjected to six treatment combinations in a three by two factorial of three competition treatments $(C$. arvense alone, C. arvense with needle and thread grass, or $C$. arvense with alkalai sacaton grass) and two herbivory treatments (with and without weevils), set in a randomized complete-block design. We did not conduct a replacementseries experiment to control for the density of plants within each pot; some pots contained C. arvense alone, whereas others contained C. arvense with a grass (two plants). Each of the six treatment combinations was randomly assigned to 2 of 12 pots within each of five replicate blocks. Typically, just one pot would have received each treatment combination, but we chose to plant two pots in the event that one was lost to mortality. In the event that $C$. arvense survived in both pots of a block, the measures were averaged over both pots and expressed as a single value. Otherwise, the measures represented individual responses to treatments. In no case did we loose both pots for a treatment combination within a block. As the harvests and measures could not be completed across all blocks within 1 or $2 \mathrm{~d}$, we chose to harvest on a block-byblock basis. Therefore, the blocks represented a source of variation both among harvest dates and among greenhouse bench positions. Aboveground and belowground biomass of C. arvense was harvested to examine differences among the six treatments.

In addition to the above treatment combinations, each grass species was grown alone to provide comparisons for grass growth in the competition and herbivory treatment combinations. Consequently, for analysis of each grass species, there were three treatment combinations: each grass species grown alone, each grown with $C$. arvense, or each grown with $C$. arvense under weevil herbivory. Grass biomass within each grass species was analyzed separately, in the same way as $C$. arvense biomass, except that treatments were fewer (three). Biomass of each grass grown with C. arvense was obtained from the same treatments (and pots) from which we obtained the biomass of $\mathrm{C}$. arvense plants. 


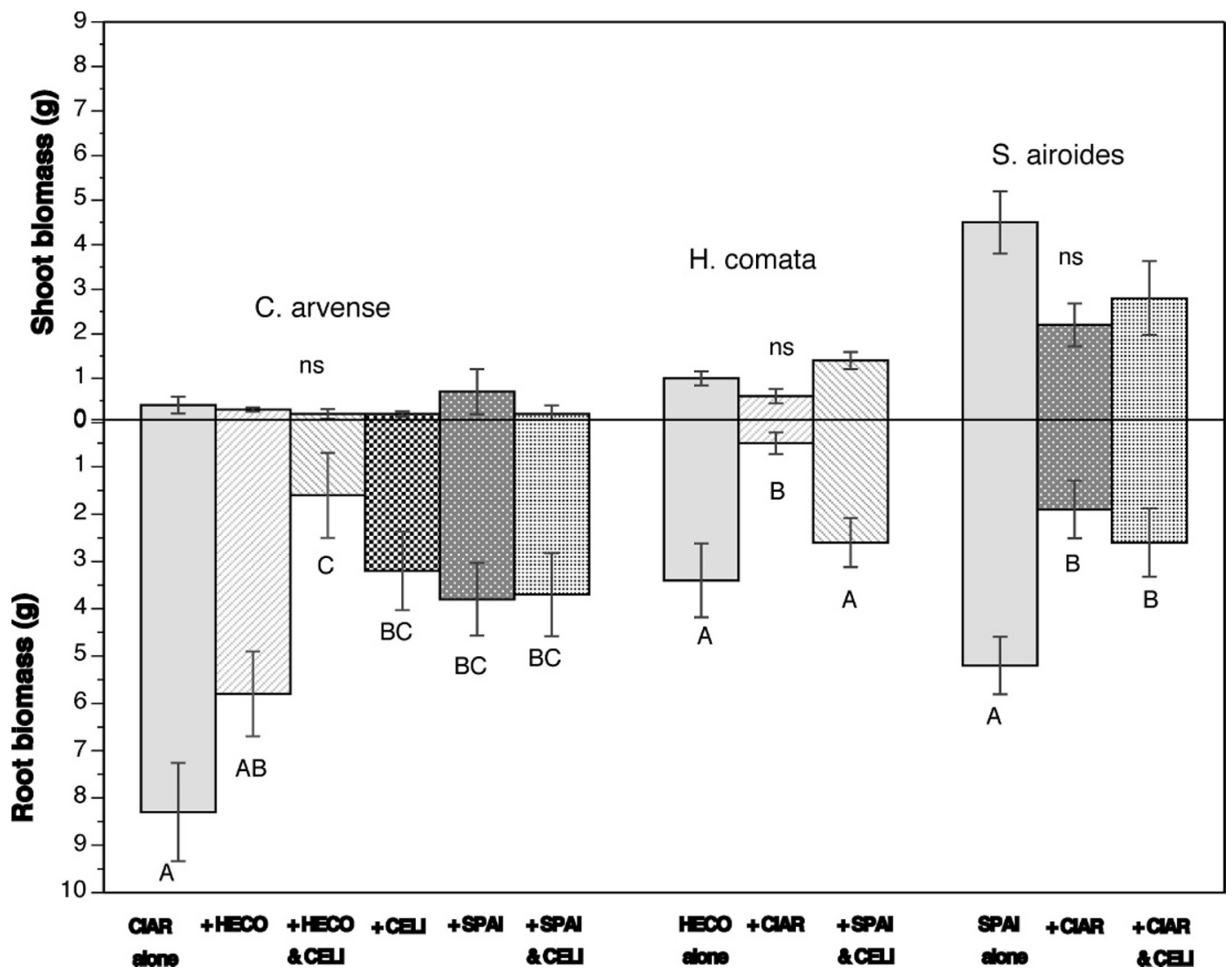

Figure 1. Biomass of Canada thistle (Cirsium arvense; CIAR) and two native grasses-needle and thread (Hesperostipa comata; HECO) and alkali sacaton (Sporobolus airoides; SPAI)—grown alone, grown in competition, and grown with the weevil Ceutorhynchus litura (CELI). Within a species and a plant portion (shoot or root) columns with the same letters do not differ significantly $(P>0.05$, Least Significant Difference). Shoot biomass of $C$. arvense and $S$. airoides did not differ among treatments (ns). Biomass values are means of five replicate blocks harvested from 25 wk to 33 wk after treatments were imposed.

Synergy between competition and herbivory was also examined for each species separately, in a two by two factorial (competition $\times$ herbivory) analysis of variance (ANOVA) set in a randomized complete-block design (SAS 2002). A lack of statistical interaction between herbivory and competition was interpreted as evidence of independent, additive effects. Rees and Brown (1992) have argued, on theoretical grounds, that synergism between herbivory and competition should appear as greater-than-additive effects of the two factors on natural logtransformed biomass. In our analyses, residuals from untransformed biomass analyses were normally distributed, and

Table 1. Canada thistle (Cirsium arvense; CIAR) shoot emergence, leaf area, and mortality in competition with needle and thread (Hesperostipa comata; HECO), with alkali sacaton (Sporobolus airoides; SPAI), and with weevil (Ceutorhynchus litura) biocontrol treatments.

\begin{tabular}{|c|c|c|c|}
\hline Treatment & Shoots, no. (SE) & Leaf area, $\mathrm{cm}^{2}$ (SE) & $\%$ mortality \\
\hline CIAR alone & $4.6(0.82)$ & $74.8(19.0)$ & 0 \\
\hline CIAR + weevil & $3.6(0.56)$ & $51.4(8.5)$ & 10 \\
\hline $\mathrm{CIAR}+\mathrm{HECO}$ & $3.8(0.44)$ & $80.1(14.5)$ & 0 \\
\hline CIAR + HECO + weevil & $2.1(0.43)$ & $42.5(9.3)$ & 40 \\
\hline $\mathrm{CIAR}+\mathrm{SPAI}$ & $3.2(0.70)$ & $53.3(17.0)$ & 5 \\
\hline CIAR + SPAI + weevil & $2.4(0.52)$ & $48.9(15.5)$ & 30 \\
\hline
\end{tabular}

${ }^{1}$ Chi-square $P=0.013$. natural $\log$ transformation was not needed to comply with the assumptions of ANOVA. When $\mathrm{F}$ tests were significant $(\alpha \leq 0.05)$ in any of these analyses, mean comparisons between treatments were made using Fisher's Protected Least Significant Difference test.

\section{RESULTS}

No Canada thistle died when grown alone, but thistle mortality was $10 \%$ following weevil addition (Table 1 ). Thistle mortality increased when we combined weevils with competition from $H$. comata (Chi-square $P=0.013$ ). No thistle mortality was recorded when $H$. comata was grown with the thistle without weevils. Canada thistle leaf area and number of shoots were highly variable (Table 1), and thistle shoot numbers $\left(\mathrm{F}_{5,20}=1.46, P=0.22\right)$ or leaf area $\left(\mathrm{F}_{5,20}=0.75, P=0.59\right)$ did not differ among treatments.

At the time of harvest, actual thistle biomass was held primarily in roots, rather than shoots, whereas grass biomass was more equally divided between roots and shoots (Fig. 1). Final shoot biomass of $C$. arvense did not differ among treatments $\left(\mathrm{F}_{5,20}=1.26, P=0.31\right)$. By contrast, final root biomass was significantly impacted by competition $\left(\mathrm{F}_{1,29}=4.02, \quad P=0.03\right)$ and herbivory $\left(\mathrm{F}_{1,29}=12.89\right.$, $P=0.0012)$. Weevil attack and competition from $H$. comata 
had independent, additive effects on thistle root biomass (weevil $\times H$. comata interaction: $\mathrm{F}_{1,26}=1.52, P=0.225$ ). Unexpectedly, weevil attack and competition from $S$. airoides showed evidence of subadditivity (weevil $\times S$. airoides interaction: $\left.F_{1,26}=19.36, P<0.001\right)$. The combination of these two factors had no more effect on C. arvense root biomass than the individual factors alone (Fig. 1).

Root biomass of $H$. comata was reduced by competition from C. arvense $\left(\mathrm{F}_{2,8}=7.56, P=0.014\right)$, although shoot biomass did not differ with the presence of $C$. arvense $\left(\mathrm{F}_{2,8}=4.14, \quad P=0.0583\right.$; Fig. 1$)$. When $C$. arvense was attacked by weevils, however, both root and shoot biomass of $H$. comata were comparable to that of $H$. comata grown alone. Thus, attack of C. arvense by the weevils increased the final root biomass of neighboring $H$. comata.

Shoot biomass of $S$. airoides was similar when grown alone vs. when grown with $C$. arvense, irrespective of weevil attack $\left(\mathrm{F}_{2,8}=2.51, P=0.1428\right)$. Root biomass of $S$. airoides was smaller in competition with C. arvense, again, irrespective of weevil attack $\left(\mathrm{F}_{2,8}=7.0, P=0.0175\right)$. Weevil attacks on $C$. arvense did not increase the root biomass of neighboring $S$. airoides.

\section{DISCUSSION}

The effects of herbivory combined with competition had additive impacts, although our results are mixed. Our results follow studies that apply integrated control methods, such as Collier et al. (2007), who found integrated competition and herbicide treatments were additive, rather than synergistic.

Neither herbivory nor competition reduced aboveground biomass of C. arvense. In our study, impacts on final shoot biomass were not significant. Collier et al. (2007) documented reduced shoot growth of the weevil and herbicide treatments on Canada thistle, but their plants were grown in noncompetitive plantings, which may have allowed greater shoot growth, and their herbicide treatments would have imposed a more direct impact on shoots. In contrast, our thistle root biomass was impacted by both herbivory and competition. Had we focused only on shoot biomass, or conducted a field study where we could not recover root biomass, none of the patterns we observed would have been apparent.

We hypothesized that grass competition and herbivory would have synergistic effects. Neither grass species had synergistic impacts on C. arvense when combined with herbivory. Competition from the cool-season grass, H. comata, and weevil attack had independent, additive effects on root biomass of C. arvense. Combining H. comata and the weevil led to greater suppression than either factor alone, but the combined impact was no greater than could be expected from their independent effects. By contrast, competition from the warm-season grass, $S$. airoides, combined with weevil attack had subadditive effects. In other words, the combination of $S$. airoides and the weevil resulted in no greater suppression of $C$. arvense root biomass than competition or herbivory alone. These results should be used with some caution, because the growing conditions in the greenhouse may have favored the warm-season grass over the cool-season grass. Field studies are needed to complement these particular results.
We also tested the hypothesis that the weevil would indirectly benefit the grasses grown with $C$. arvense. The indirect impacts of the weevil on the grasses also differed between the grass species, supporting our hypothesis in the case of $H$. comata but not $S$. airoides. As expected, responses of the two grasses differed; the cool-season grass $H$. comata gained benefit from damage to $C$. arvense inflicted by the weevil, whereas $S$. airoides did not. Nevertheless, our results for both grass species differ from those of Callaway et al. (1999), who studied the indirect effects of herbivory on the invasive spotted knapweed and found that knapweed plants damaged by the root-boring moth, Agapeta zoegana, had a greater competitive effect on Idaho fescue (Festuca idahoensis Elmer) than undamaged knapweeds. Thus, root herbivory on spotted knapweed had a negative, indirect effect on neighboring Idaho fescue, although, in additional experiments, herbivores did not indirectly impact the grass (Newingham and Callaway 2006).

\section{IMPLICATIONS}

Combining insect herbivory and competition from native plants to manage invasive species can result in a wide variety of outcomes. Recently, several researchers have advocated integrating restoration seedings on rangelands with biological controls to combat invasive species (Headrick and Goeden 2001; Denslow and D'Antonio 2005; Lym 2005). However, integrating these approaches requires us to identify the most competitive native plant species for a specific invader and also to determine native competitor compatibility with the biological control agents. A systematic approach can be used to evaluate specific phenologic combinations of competitive natives and biological control agents to reveal patterns of timing that enhance the effectiveness of the combined activity against invasive species. In this study, we examined temporal mechanisms behind the additive vs. subadditive effects of combining a cool-season vs. a warm-season grass with $C$. litura. We suspect that the timing of competition and of weevil activity, relative to the ability of $C$. arvense to compensate for stressors (Peschken and Derby 1992; Hein and Robert 2004), play important roles in determining the outcome of integrated controls of invasive species.

\section{ACKNOWLEDGMENTS}

We thank Drs S. F. Enloe and S. D. Miller for early input, Dr D. E. Legg for statistical consultation, anonymous reviewers for their helpful comments, and research technicians Patrick Madsen, Elisabeth Parrish, Morgan Wolvington, Rachel Mealor, and Sarah Tyrer for their assistance and diligence.

\section{LITERATURE CITED}

Ang, B. N., L. T. KoK, G. I. Holtzman, and D. D. Wolf. 1994. Competitive growth of Canada thistle, tall fescue and crownvetch in the presence of a thistle defoliator, Cassida rubignosa Muller (Coleoptera, Chrysomelidae). Biological Control 4:277-284. 
Ang, B. N., L. T. Kok, G. I. Holtzman, and D. D. Wolf. 1995. Canada thistle (Cirsium arvense (L) Scop) response to density of Cassida rubignosa Muller (Coleoptera, Chrysomelidae) and plant competition. Biological Control 5:31-38.

Callaway, R. M., T. H. Deluca, and W. M. Belliveau. 1999. Biological-control herbivores may increase competitive ability of the noxious weed Centaurea maculosa. Ecology 80:1196-1201.

Callaway, R. M., and W. M. Ridenour. 2004. Novel weapons: invasive success and the evolution of increased competitive ability. Frontiers in Ecology and the Environment 2:436-443.

Collier, T. R., S. F. Enloe, J. K. Sciegienka, and F. D. Menall. 2007. Combined impacts of Ceutorhynchus litura and herbicide treatments for Canada thistle suppression. Biological Control 43:231-236.

Coombs, E. M., J. K. Clark, G. L. Piper, and A. J. Cofrancesco. 2004. Biological control of invasive plants in the United States. Corvallis, OR, USA: Oregon State University Press. 448 p.

Denslow, J. S., And C. M. D’Antonio. 2005. After biocontrol: assessing indirect effects of insect releases. Biological Control 35:307-318.

HarRIS, P. 1973. The selection of effective agents for the biological control of weeds. Canadian Entomologist 105:1495-1503.

HaRRIS, P. 1991. Classical biocontrol of weeds: its definitions, selection of effective agents, and administrative-political problems. The Canadian Entomologist 123:827-849

Headrick, D. H., and R. D. Goeden. 2001. Biological control as a tool for ecosystem management. Biological Control 21:249-257.

Hein, G. L., AND W. Robert. 2004. Impact of Ceutorhynchus litura feeding on root carbohydrate levels in Canada thistle (Cirsium arvense). Weed Science 52:628-633.

Keane, R. M., and M. J. Crawley. 2002. Exotic plant invasions and the enemy release hypothesis. Trends in Ecology \& Evolution 17:164-170.

LYM, R. G. 2005. Integration of biological control agents with other weed management technologies: successes from the leafy spurge (Euphorbia esula) IPM program. Biological Control 35:366-375.

MealoR, B. A., AND A. L. HILD. 2006. Potential selection in native grass populations by exotic invasion. Molecular Ecology 15:2291-2300.

MülleR-Schärer, H. 1991. The impact of root herbivory as a function of plant density and competition: survival, growth and fecundity of Centaurea maculosa (Asteraceae) in field plots. Journal of Applied Ecology 28:759-776.

Müller-Schärer, H., and D. Schroeder. 1993. The biological control of Centaurea spp. in North America: do insects solve the problem? Pesticide Science 37:343-353.

Myers, J. H., and D. R. Bazely. 2003. Ecology and control of introduced plants Cambridge, United Kingdom: Cambridge University Press. 328 p.

Nadeau, L. B., and W. H. Vandenborn. 1989. The root system of Canada thistle. Canadian Journal of Plant Science 69:1199-1206.
Newingham, B. A., and R. M. Callaway. 2006. Shoot herbivory on the invasive plant, Centaurea maculosa, does not reduce its competitive effects on conspecifics and natives. Oikos 114:397-406.

Notzold, R., B. Blossey, and E. Newton. 1998. The influence of below ground herbivory and plant competition on growth and biomass allocation of purple loosestrife. Oecologia 113:82-93.

Peschken, D. P., and J. L. Derby. 1992. Effects of Urophora cardui (L) (Diptera, Tephritidae) and Ceutorhynchus litura (F) (Coleoptera, Curculionidae) on the weed Canada thistle, Cirsium arvense (L) Scop. Canadian Entomologist 124:145-150.

Peschken, D. P., and A. T. S. Wilkinson. 1981. Biocontrol of Canada thistle (Cirsium arvense)-releases and effectiveness of Ceutorhynchus litura (Coleoptera, Curculionidae) in Canada. Canadian Entomologist 113:777-785.

Piper, G. L., and L. A. Andres. 1995. Canada thistle. In: J. R. Nechols [ed.]. Biological control in the western United States. Oakland, CA, USA: University of California. p. 233-236.

Reed, C. C., D. L. Larson, and J. L. Larson. 2006. Canada thistle biological control agents on two South Dakota wildlife refuges. Natural Areas Journal 26:47-52.

ReEs, N. E. 1990. Establishment, dispersal and influence of Ceutorhynchus litura on Canada thistle (Cirsium arvense) in the Gallatin Valley of Montana. Weed Science 38:198-200.

ReES, M., AND V. K. Brown. 1992. Interactions between invertebrate herbivores and plant competition. Journal of Ecology 80:353-360.

SAS [computer program]. 2002. JMP Statistical Discovery Software, Version 5. Cary, NC, USA: SAS Institute Inc.

Sheppard, A. W. 1996. The interaction between natural enemies and interspecific plant competition in the control of invasive pasture weeds. In: V. C. Moran and J. H. Hoffman [EDS.]. Proceedings of the IXth International Symposium on the Biological Control of Weeds; 19-26 January 1996; Stellenbosch, South Africa. Cape Town, South Africa: University of Cape Town. p. 47-53.

Sheppard, A. W., M. J. Smyth, and A. SwirepIK. 2001. The impact of a root-crown weevil and pasture competition on the winter annual Echium plantagineum. Journal of Applied Ecology 38:291-300.

Strauss, S. Y., J. A. Lau, and S. P. Carroll. 2006. Evolutionary responses of natives to introduced species: what do introductions tell us about natural communities? Ecology Letters 9:354-371.

[USDA-NRCS] US Department of Agriculture-Natural Resources Conservation Service [online database]. 2007. The PLANTS database. Baton Rouge, LA, USA: National Plant Data Center.

[USDA-USFS] US Department of Agriculture-US Forest Service [online database]. 2007. Fire effects information system: species descriptions. Missoula, MT, USA: Rocky Mountain Research Station, Fire Sciences Laboratory.

Wilson, R. G., and S. D. Kachman. 1999. Effect of perennial grasses on Canada thistle (Cirsium arvense) control. Weed Technology 13:83-87. 